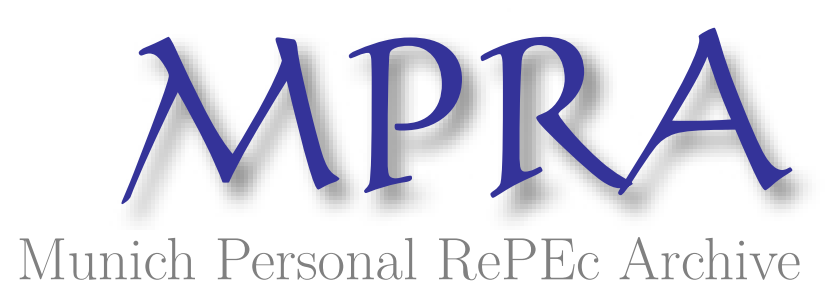

\title{
Hedge funds - evolution and perspectives
}

Ganchev, Alexander

Tsenov Academy of Economics

December 2015

Online at https://mpra.ub.uni-muenchen.de/70050/

MPRA Paper No. 70050, posted 16 Mar 2016 23:55 UTC 


\title{
HEDGE FUNDS - EVOLUTION AND PERSPECTIVES
}

\author{
Assoc. Prof. Alexander Ganchev, PhD \\ D. A. Tsenov Academy of Economics, \\ Department of Finance and Credit
}

\begin{abstract}
The article reviews and analyses the origins of the hedge fund sector and its development on a worldwide scale. The study reveals that hedge funds had arisen long before 1949 and shows that global financial crises do not occur due to hedge funds because the latter only exploit economic development disparities, the imperfections of financial systems, the inadequate regulatory frameworks or the inefficient financial market regulations that are already in place. The article shows that, although the development of the hedge fund industry is very sensitive to financial crises, their popularity as investment instruments has been increasing rather than decreasing since the last global economic crisis of 2008.
\end{abstract}

Keywords: hedge funds, financial markets, financial crises.

JEL: G01, G15, G18, G23, G28

Hedge funds are highly-leveraged collective investment schemes that invest in various asset types, usually have complex portfolio structures as well as unlimited and diverse investment vehicles, are managed by different types of legal entities and operate on a global scale. Due to the specifics of their activities (which are often shrouded in mystery), but mostly because of their staggering performance, the characteristics of their investment and risk management strategies have stirred the interest of many foreign researchers ${ }^{1}$ in the field of portfolio

${ }^{1}$ For more details see Lavinio, S. The Hedge Fund Handbook: A Definitive Guide for Analyzing and Evaluating Alternative Investments. McGraw-Hill Professional, 1999; Gregoriou, G. 
management and alternative investments. However, most studies on the nature and behaviour of hedge funds seem to regard the questions related to their genesis and evolution as unimportant or insignificant. This is especially true for the studies conducted by Bulgarian financial and investment theorists. Their publications in the field of hedge funds (e.g. the study by Yordan Yordanov published in 2002, S. Dimov's article published in $2007^{2}$ and the article by K. Georgiev published in 2009 ${ }^{3}$ ) focus only on the general characteristics of hedge funds and pay very little attention to the analysis of their origins and the characteristics of their development worldwide. This is why this article is focused mainly on the historical development of hedge funds and its main objective is to define the characteristics of their evolution.

$$
* * *
$$

Collective investment schemes emerged and developed as financial institutions to satisfy a specific economic demand. This demand stemmed from the willingness of certain economic agents to manage their wealth more efficiently. Unlike traditional individual investment schemes, collective investments in real, financial or liquid assets are managed professionally, achieve a profitability that matches different risk preferences, have more efficient risk management and achieve an economy of scale in terms of the cost of investment operations. Since hedge funds are collective investment schemes, they all have the above characteristics. Hedge funds originated and evolved long before the beginning of collective investment worldwide. According to research

N., Karavas, V. N., Rouah, F. Hedge Funds: Strategies, Risk Assessment, and Returns. Beard Books, 2003; McCrary, S. A. Hedge Fund Course. John Wiley \& Sons, 2004; Nicholas, J.G. Investing In Hedge Funds. John Wiley \& Sons, 2005.

${ }^{2}$ Dimov, S. Hedge fondovete - edna ot novite i moderni tendentsii na finansovite pazari. // Biznes posoki, Tsentara po ikonomicheski i upravlenski nauki - Burgaski svoboden universitet, vol. 1, 2007, pp. 20-35.

${ }^{3}$ Georgiev, K. Evolyutsionni harakteristiki na kolektivnite shemi za investitsii v tsenni knizha. // Narodnostopanski arhiv, vol. 1, 2009, pp. 82-96. 
conducted by Rouwenhorst ${ }^{4}$, the beginning of collective investment in securities was undoubtedly in 1774, when the Eendragt Maakt Magt fund was established in the Netherlands. Undoubtedly, hedge funds are indisputably a product of the 20th century. They continued to develop intensively even during the second half of the century. This means that there were certain reasons for their existence as financial institutions that a traditional analysis of the historical development of collective investment cannot identify. Moreover, an analysis of their historical development and the reasons for the emergence of various financial institutions is the first important step in the process of defining their institutional characteristics. In Bulgaria, this approach was adopted and described by Stefan Stefanov ${ }^{5}$ in his study dedicated to investment banking. It has also been adopted in this study.

Most foreign research publications ${ }^{6}$ on issues related to hedge funds identify 1949 as the year of their emergence, because in this year Alfred Jones created an investment fund that adopted a strategy of long and short positions in equity securities. The same opinion was expressed in the publications of Yordan Yordanov ${ }^{7}$, Sava Dimov ${ }^{8}$ and Krasimir Georgiev ${ }^{9}$.

This common opinion regarding the emergence of hedge funds is not based on scientific research but on Loomis' article published in Fortune magazine in $1966^{10}$, which described the activities of the A.W. Jones \& Co fund created in 1949 by Alfred Jones. The article, which 2004, p. 3 .

${ }^{4}$ Rouwenhorst, K. G. The Origins of Mutual Funds. Yale ICF Working Paper No. 04-48,

${ }^{5}$ Stefanov, S. Investitsionno bankirane. V. Tarnovo, Abagar, 2005.

${ }^{6}$ For more details see Eichengreen, B. J., Mathieson, D. J., Chadha, B. Hedge Funds and Financial Market Dynamics. International Monetary Fund, 1998, p. 27; Gregoriou, G. N., Rouah, F., Sedzro, K. Performance Evaluation of Hedge Funds. Beard Books, 2003, p. 1; Anson, M. J. P. Handbook of Alternative Assets. John Wiley \& Sons, 2006, p. 36; Gros, F. Hedge Fund Strategies - a Critical Review. GRIN Verlag, 2007, p. 2; Vishwanath, R. Investment Management: A Modern Guide to Security Analysis and Stock Selection. Springer, 2009, p. 594; Wilson, R. C. The Hedge Fund Book: A Training Manual for Professionals and Capital-Raising Executives. John Wiley \& Sons, 2011, p. 8; Strachman, D. A. Getting Started in Hedge Funds: From Launching a Hedge Fund to New Regulation, the Use of Leverage, and Top Manager Profiles. John Wiley \& Sons, 2011, p. 17.

${ }^{7}$ Yordanov, Y. Op. cit., pp. 25-27.

${ }^{8}$ Dimov, S. Op. cit., pp. 23-24.

${ }^{9}$ Georgiev, K. op. cit., p. 88.

${ }^{10}$ Loomis, C. The Jones Nobody Keeps Up With. // Fortune, April, 1966, pp. 237-247. 
described the remarkable results achieved by the fund during a period of stagnation in the US capital market, referred for the first time to this type of structure as a "hedge fund". Since then the term has become a byword for all investment funds that adhere to strategies similar to that of the fund created by Alfred Jones. This is why many people wrongly assume that the fund created by Alfred Jones was the first "hedge fund". However, to assume that the term used to characterize a particular financial structure is sufficient evidence that this particular institution was the first of its kind is scientifically frivolous and superficial because, in the field of finance, what is important is not so much the term used to define a given institution, but its functional organisation and purpose. Recent developments have shown that the process of the emergence of hedge funds and their subsequent development is much more complex than it was traditionally assumed.

In 2009, Longo ${ }^{11}$ described a meeting he had had with Warren Buffett, during which the prominent financier and philanthropist expressed his opinion that the first hedge fund could have been the Benjamin Graham Joint Account fund established in 1926 by Benjamin Graham. This fund had three distinctive characteristics ${ }^{12}$ :

First. It was established and operated as a partnership, i.e. it was not a public legal entity.

Second. Like traditional investment funds, the Benjamin Graham Joint Account adopted an investment policy for achieving longterm results based on an increase in the value of the equity securities it invested in. However, this investment policy also included short positions as well as investments in debt instruments of bankrupt entities.

Third. The Fund Manager's remuneration depended on the performance of the fund rather than the total value of the managed portfolio.

11 Longo, J. M. Hedge Fund Alpha: A Framework for Generating and Understanding Investment Performance. World Scientific, 2009, p. 3-4.

12 Ibid. p. 3-4. 
The above characteristics and especially the investment policy and the formation of the Fund Manager's remuneration did not pertain to any other collective investment scheme that operated in the USA at that time, such as the investment companies' Alexander Fund ${ }^{13}$ and Massachusetts' Investors' Trust ${ }^{14}$.

An even more interesting fact related to the origins of the hedge funds is Karl Karsten's research paper published in $1931 .{ }^{15}$ It includes a detailed description of the principles of hedge fund management by means of a hedging investment strategy that includes both long and short positions in securities. What is more, one year prior to the publication, Karsten had created an investment fund and had adopted the same investment strategy to manage it. In 2004, Dennistoun wrote that, for about seven months after its creation, Karsten's fund achieved a huge positive return despite the situation on the capital markets in that period. ${ }^{16}$ However, the mystery does not end here. In his publication, Karsten refers to yet another seemingly startling fact - that during the same period a competitive investment fund was operating following the same investment policy. ${ }^{17}$ This undoubtedly proves that the investment strategies adopted by hedge funds today were used long before 1949. Moreover, the fact that, prior to the establishment of the A. W. Jones \& Co. fund there were at least three legal entities that adhered to investment approaches that are characteristic for hedge funds or very similar to their investment strategies, means that this process was not incidental and is based on sound principles.

A comparative analysis of the Alfred Jones' fund shows that its characteristics did not differ significantly from the characteristics of the funds created by Benjamin Graham and Karl Karsten. However, some of

\footnotetext{
${ }^{13}$ For more details see Robertson, R. A. Fund Governance: Legal Duties of Investment Company Directors. Law Journal Press, 2001, p. 10-11.

${ }^{14}$ For more details see Fink, M. The Rise of Mutual Funds: An Insider's View. Oxford University Press, 2008, p. 10-11 и Lowenstein, L., Barsky, N. The Investor's Dilemma: How Mutual Funds Are Betraying Your Trust And What To Do About It. John Wiley \& Sons, 2008, p. 11-12.

${ }^{15}$ Karsten, K. G. Scientific forecasting. New York, Greenberg, 1931.

16 Dennistoun, C. Karsten, Jones and the Origin of Hedge Funds. Eurekahedge news document, 2004. http://www.eurekahedge.com/news/04may_archive_origin_of_hedge_funds.asp.

${ }^{17}$ Karsten, K. G. Ibid, p.174.
} 
these characteristics must be considered in greater detail. In order to avoid the strict regulations of the Investment Company Act of $1940,{ }^{18}$ Alfred Jones registered his funds as a general partnership in which he was a general partner with unlimited liability and the investors had limited liability. Thus, unlike traditional investment funds, he could follow a flexible investment policy by also being able to pool the resources of external investors.

The underlying principles of the investment policy adopted by the A. W. Jones \& Co. fund were exactly the same as that of Karl Karsten's fund. The only difference was that it combined investment decisions with financial. What is interesting here is that this had happened nine years before Tobin's publication of his Separation Theorem. ${ }^{19}$ Specifically, Alfred Jones re-invested the return from the short positions into securities. Thus, he created a leverage effect on his fund's return, which means that the return could be multiplied when the market processes related to his long positions were favourable but at the same time, losses could also be significantly increased when the short positions were not set correctly. In the second case, the losses can offset the hedging effect of the adopted investment policy. Essentially, the use of leverage was the first significant financial innovation made by Alfred Jones. Its importance is proved by the fact that today there are no hedge funds around the world that do not include this extremely risky approach in their management policies.

Alfred Jones imposed yet another standard in the hedge fund sector - the rule that the fund's performance fee should be $20 \%$ of its profits. ${ }^{20}$ The management costs are shared at a twenty to eighty percentage rate

\footnotetext{
18 For more details see U. S. Securities and Exchange Commission (SEC). Investment Company Act of 1940, 1940. http://www.sec.gov/ about/laws/ica40.pdf.

${ }^{19}$ For more details see Tobin, J. Liquidity preference as behavior towards risk. // Review of Economic Studies, 25 (67), 1958, p. 65-86.

${ }^{20}$ Lhabitant, F. Handbook of Hedge Funds. John Wiley \& Sons, 2006, p. 7.
} 
between the general partner and the partners with limited liability ${ }^{21}$, i.e. the investors.

The above facts show that the investment fund established by Alfred Jones in 1949 was an important point in the development of the collective investment schemes and investment funds that follow hedging strategies. It introduced the management principles that are adhered to by hedge funds today. This is why the A. W. Jones \& Co. fund is undoubtedly the first modern hedge fund. However, it is not the first financial institution that marked the beginning of the process of hedge fund development. This process was facilitated by the rise of the capital market in the United States after World War II. This intensive development and the increasing popularity of leveraging by combining long and short positions were the drivers behind the rapid development of hedge funds. The periods of most intensive development were the years between 1966 and 1968, when, according to a survey conducted by Frush, ${ }^{22}$ some 140 new hedge funds were created. In this period, the careers of some of the most prominent hedge fund managers began, such as Michael Steinhardt and George Soros, who created their hedge funds in 1967 and 1969 respectively. ${ }^{23}$

Economic stagnation and the oil crisis in the early 70s, whose effects continued until the early 80 s, had a serious impact on the development of hedge funds worldwide. Their negative effects were described by Pompian in his 2009 study $^{24}$, in which he points out that, by 1984 , the crisis in the sector had reduced the number of hedge funds to only 68 institutions. The dynamic development of financial markets worldwide in the process of their recovery created new opportunities for the development of hedge funds. In 1986, Rohrer ${ }^{25} 1986$ described the

\footnotetext{
${ }^{21}$ Ibid, p. 7.

${ }^{22}$ Frush, S. Understanding Hedge Funds. McGraw-Hill Professional, 2006, p. 32.

${ }^{23}$ For more details see Stefanini, F. Investment Strategies of Hedge Funds. John Wiley \& Sons, 2006, pp. 2-3. 2009, p. 188.

${ }^{24}$ Pompian, M. M. Advising Ultra-Affluent Clients and Family Offices. John Wiley \& Sons, 86-92.

${ }^{25}$ Rohrer, J. The red hot world of Julian Robertson. // Institutional investor, May, 1986, pp.
} 
activities of the Tiger Fund, which was founded by Julian Robertson in 1980. Unlike the traditional approach applied by hedge funds, it invested in a globally diversified portfolio of assets selected on the basis of a thorough analysis of various macroeconomic and political variables. Due to this innovative investment strategy, the Tiger Fund reported a 43 per cent return net of fees. ${ }^{26}$ The subsequent years of hedge fund development were just as interesting and dynamic. The 1987 crisis in the financial markets of the USA and its global impact inevitably affected existing hedge funds, which did not manage to cover their incurred losses until 1989.

One of the milestones in the history of the hedge fund industry is 1992, when the globally-investing Quantium Fund managed by George Soros spectacularly attacked the overvalued British pound with short selling while forming mirror long positions in German marks. This forced the Bank of England to withdraw the British pound from the European Exchange Rate Mechanism, which was later transformed into the single European currency. The Quantium Fund's net profit from this operation was over one billion US dollars. A few years later, in 1997, hedge funds were finally given their notoriously bad name during the Asian financial crisis. Taking advantage of the overvalued economic growth, and the speculatively high prices of financial, liquid and real assets in a number of Asian economies, hedge funds generated significant profits only by forming huge short positions. A study by the Financial Stability Forum published in 2000 indicates that the cause of the turmoil in the Asian financial markets was the behaviour of highly-leveraged financial institutions, i.e. mostly hedge funds. ${ }^{27}$ This shows that their influence on the processes of financial markets in the last decade of the 20th century was growing due to three reasons:

\footnotetext{
${ }^{26}$ Guizot, A. The Hedge Fund Compliance and Risk Management Guide. John Wiley \& Sons, 2007, p. 1

${ }^{27}$ For more details see Financial Stability Forum. Report of the Working Group on Highly Leveraged Institutions, FSB Publications, 2000. http://www.financialstabilityboard.org/ publications/r_0004a.pdf.
} 
First. Hedge funds already operate globally and financial markets are becoming more integrated. This diversifies the potential investment strategies and creates new opportunities for making profits provided that there are favourable conditions on any capital market around the world.

Second. Hedge funds had already pooled vast amounts of financial resources, which, under certain conditions, can affect the dynamics and the development of some individual national or regional financial markets.

Third. The lack of strict regulations and supervision of hedge funds leads to situations in which only they have the resources and opportunities to exploit weaknesses in the financial markets. Therefore, we can conclude that financial crises are not caused by hedge funds. They occur due to economic development disparities, imperfections in financial systems, inadequate regulatory frameworks or ineffective regulations. Hedge funds only exploit these weaknesses and aggravate them in order to make a profit. This has resulted in the popular misconception that highly leveraged investment funds are the cause of most of the financial woes in the world.

An important point in the development of hedge funds, which also raises questions about their role in the global financial market and the regulation of their activities, is the bankruptcy of the Long Term Capital Management fund in 1998. It was caused mainly by the fund's large leveraged position in debt securities, which incurred a loss of more than 4 billion US dollars due to the Russian financial crisis. The repercussions on the financial markets made the US Federal Reserve actively intervene in order to minimize the losses for various institutions. ${ }^{28}$ This, however, forever changed public opinion regarding the role of hedge funds. All financial institutions and regulators imposed stricter supervision on their activities, required more information regarding their operations and

28 За повече подробности по отношение приетите мерки от Федералния резерв на САЩ вж. Essvale Corporation Limited. Business Knowledge for It in Hedge Funds. Essvale Corporation Limited, 2008, p. 8. 
imposed restrictions against the uncontrolled increase of their leverage and hence the emergence of systemic risk to the entire financial sector.

Despite the bankruptcy of Long Term Capital Management and the dotcom bubble crisis, hedge funds boomed in the beginning of the $21^{\text {st }}$ century. This is proved by the statistics quoted by Lo. In September 2007, there were 4266 hedge funds and, in the period 1977-2007, their number totalled $7924 .^{29}$ The global financial crisis of 2008 and the new series of scandals, among which the most notable was that related to the financial pyramid organized by the Bernard L. Madoff Investment Securities LLC hedge fund, once again put to the test hedge funds around the world and hindered their development. BarclayHedge's statistics for 2015 show that the company's database of hedge funds operating on a global scale contains data for $3427^{30}$ single manager highly-leveraged institutions, which is down by over $19.67 \%$ compared to the period before the outbreak of the global financial crisis. However, as of the $3^{\text {rd }}$ Quarter 2015, the total assets under management for the hedge fund industry were estimated at $\$ 2712.8$ billion. ${ }^{31}$ This represents a growth of over $86.08 \%$ compared to $\$ 1457.9$ billion in $2008 .{ }^{32}$ These facts mean only one thing. The global financial crisis has purged the industry of inefficient players and it still enjoys high popularity among investors.

$* * *$

The main conclusions that can be drawn from the research presented in this article throw new light on the origins and development of hedge funds. The chronological analysis reveals that such funds were established much earlier than was commonly believed. On the other hand, the important stages in the development of the hedge fund industry are

\footnotetext{
${ }^{29}$ See Lo, A. W. Hedge Funds: An Analytic Perspective. Princeton University Press, 2008, p. 34-35.

${ }^{30} \mathrm{http}: / / \mathrm{www} \cdot$ barclayhedge.com/products/hedge-fund-directory.html.

${ }^{31} \mathrm{http}: / / \mathrm{www}$. barclayhedge.com/research/money_under_management.html.

${ }^{32}$ For more detailed statistics see http://www.barclayhedge.com/research/indices/ghs/mum/ Hedge_Fund.html
} 
marked by financial crises to which hedge funds and their operations are very sensitive. A feature that is common for all financial crises is that they change the sector. The trends that are common for all periods are hedge funds following an extremely aggressive investment policy, the increasingly stringent requirements for their transparency and stricter institutional regulations. Global financial processes since 2008 also follow suit. Nevertheless, the popularity of hedge funds as alternative investment vehicles keeps increasing.

\section{References:}

1. Georgiev, K. Evolyutsionni harakteristiki na kolektivnite shemi za investitsii v tsenni knizha. // Narodnostopanski arhiv, vol. 1, 2009.

2. Dimov, S. Hedge fondovete - edna ot novite i moderni tendentsii na finansovite pazari. // Biznes posoki, Tsentara po ikonomicheski i upravlenski nauki - Burgaski svoboden universitet, vol. 1, 2007.

3. Yordanov, Y. Investitsionni fondove - struktura, menidzhmant, otsenka. Varna, ET Peevi, 2002.

4. Stefanov, S. Investitsionno bankirane. V. Tarnovo, Abagar, 2005.

5. Anson, M. J. P. Handbook of Alternative Assets. John Wiley \& Sons, 2006.

6. Dennistoun, C. Karsten, Jones and the Origin of Hedge Funds. Eurekahedge news document, 2004. http://www.eurekahedge.com/news/04may_ archive_origin_of_hedge_funds.asp.

7. Eichengreen, B. J., Mathieson, D. J., Chadha, B. Hedge Funds and Financial Market Dynamics. International Monetary Fund, 1998.

8. Essvale Corporation Limited. Business Knowledge for It in Hedge Funds. Essvale Corporation Limited, 2008.

9. Financial Stability Forum. Report of the Working Group on Highly Leveraged Institutions, FSB Publications, 2000. http://www.financialstabilityboard.org/publications/r_0004a.pdf

10. Fink, M. The Rise of Mutual Funds: An Insider's View. Oxford University Press, 2008, p. 10-11

11. Frush, S. Understanding Hedge Funds. McGraw-Hill Professional, 2006.

12. Gregoriou, G. N., Karavas, V. N., Rouah, F. Hedge Funds: Strategies, Risk Assessment, and Returns. Beard Books, 2003.

13. Gregoriou, G. N., Rouah, F., Sedzro, K. Performance Evaluation of Hedge Funds. Beard Books, 2003. 
14. Gros, F. Hedge Fund Strategies - a Critical Review. GRIN Verlag, 2007.

15. Guizot, A. The Hedge Fund Compliance and Risk Management Guide. John Wiley \& Sons, 2007 1931.

16. Karsten, K. G. Scientific forecasting. New York, Greenberg,

17. Lavinio, S. The Hedge Fund Handbook: A Definitive Guide for Analyzing and Evaluating Alternative Investments. McGraw-Hill Professional, 1999.

18. Lhabitant, F. Handbook of Hedge Funds. John Wiley \& Sons, 2006.

19. Longo, J. M. Hedge Fund Alpha: A Framework for Generating and Understanding Investment Performance. World Scientific, 2009.

20. Loomis, C. The Jones Nobody Keeps Up With. // Fortune, April, 1966 ,

21. Lowenstein, L., Barsky, N. The Investor's Dilemma: How Mutual Funds Are Betraying Your Trust And What To Do About It. John Wiley \& Sons, 2008.

22. McCrary, S. A. Hedge Fund Course. John Wiley \& Sons, 2004; Nicholas, J.G. Investing In Hedge Funds. John Wiley \& Sons, 2005.

23. Pompian, M. M. Advising Ultra-Affluent Clients and Family Offices. John Wiley \& Sons, 2009.

24. Robertson, R. A. Fund Governance: Legal Duties of Investment Company Directors. Law Journal Press, 2001.

25. Rohrer, J. The red hot world of Julian Robertson. // Institutional investor, May, 1986, p. 86-92.

26. Rouwenhorst, K. G. The Origins of Mutual Funds. Yale ICF Working Paper No. 04-48, 2004.

27. Stefanini, F. Investment Strategies of Hedge Funds. John Wiley \& Sons, 2006

28. Strachman, D. A. Getting Started in Hedge Funds: From Launching a Hedge Fund to New Regulation, the Use of Leverage, and Top Manager Profiles. John Wiley \& Sons, 2011.

29. Tobin, J. Liquidity preference as behavior towards risk. // Review of Economic Studies, 25 (67), 1958, p. 65-86.

30. U. S. Securities and Exchange Commission (SEC). Investment Company Act of 1940, 1940. http://www.sec.gov/ about/laws/ica40.pdf

31. Vishwanath, R. Investment Management: A Modern Guide to Security Analysis and Stock Selection. Springer, 2009.

32. Wilson, R. C. The Hedge Fund Book: A Training Manual for Professionals and Capital-Raising Executives. John Wiley \& Sons, 2011. 